\title{
PENDAMPINGAN TENTANG PEMAHAMAN MANAJEMEN SYARIAH SEBAGAI UPAYA UNTUK PENGEMBANGAN USAHA PEMBIAYAAN PADA KOPERASI SERBA USAHA'KARYA SEMBADA "PERUSDA" PUSAT PERGUDANGAN KOTA (PPK) PEDARINGAN SURAKARTA
}

\author{
Budi Poniman, Basuki Sri Rahayu, Heriyanta Budhi Utama \\ Manajemen, STIE-AUB Surakarta
}

\begin{abstract}
ABSTRAK
Koperasi serba usaha 'Karya Sembada bernaung di bawah PERUSDA Pusat Pergudangan Kota (PPK) pedaringan surakarta, yang beralamat di Jalan tentara pelajar/Kentingan no.1 Surakarta. Kegiatan pengabdian kepada masyarakat ini bertujuan memberikan pendampingan pemahaman kepada para pengurus dan anggota koperasi "Karya Sembada" dalam hal manajemen syariah khususnya sebagai upaya menuju pengelolaan pembiayaan dengan sistem syariah, yang sebelumnya masih konvensional. Sehingga diharapkan nantinya para pengurus dan anggota koperasi dalam melaksanakan tugas dan tanggungjawabnya sesuai dengan prinsip dan kaidah manajemen syariah dapat terwujud, disamping itu sebagai langkah pengembangan dibidang usaha simpan pinjam diharapkan dapat menjadi sistem pembiayaan dengan prinsip syariah. Pengabdian Masyarakat ini dilakukan dengan ceramah tentang prinsip-prinsip dasar manajemen syariah, Prinsip titipan/simpanan (Al-Wadiah) yang meliputi prinsip Al Mudharabah dan prinsip Al Musyarakah. Pendampingan tentang contoh transaksi dan masalah dari sistem pembiayaan syariah. Hasil luaran kegiatan pengabdian kepada masyarakat ini adalah pengurus dan anggota koperasi khususnya dibidang usaha simpan pinjam mampu mengetahui dan memahami serta menerapkan kegiatan usaha pembiayaan dengan sistem manajemen syariah sebagai langkah menuju pengembangan usaha pembiayaan yang selama ini masih menggunakan sistem konvensional. Luaran wajib pengabdian masyarakat ini berupa jurnal ilmiah yang akan dipublikasi.
\end{abstract}

Kata Kunci : Pengurus koperasi, prinsip dan kaidah manajemen syariah

\section{ABSTRACT}

Cooperative effort of 'Karya Sembada shelter under PERUSDA Pusat Pergudangan Kota (PPK) pedaringan surakarta, having address at Tentara Pelajar Sreet / Kentingan no.1 Surakarta. The community service is aimed to provide facilitation of understanding to the management and members of the cooperative "Karya Sembada" in terms of syariah management especially as an effort to finance management with syariah system, which previously still conventional. So it is expected that the board and members of the cooperative in carrying out their duties and responsibilities in accordance with the principles and rules of sharia management can be realized, in addition as a step development in the field of savings and loan business is expected to become a system of financing by syariah principles. Community Service is done with a lecture on the basic principles of syariah management, Stash (al-Wadiah) which includes the principle of $\mathrm{Al}$ Mudharabah and al -Musyarakah principle. Assistance to sample examples and problems of syariah financing system. Outcome / output of community service activities is the board and members of the cooperative, especially in the field of savings and loan businesses are able to know and understand and apply financing with the Islamic management system as a step toward the development of financing business that still use conventional system. Outline mandatory community service is a scientific journal to be published.

Keywords: Management of cooperatives, principles and rules of syariah management

\section{PENDAHULUAN}

Koperasi Serba Usaha "Karya Sembada" yang beralamat di J1 Tentara Pelajar/kentingan No.1 Surakarta merupakan salah satu koperasi serba usaha dibawah naungan Perusahaa Daerah (PERUSDA) Pusat Perdagangan Kota (PPK) Pedaringan Surakarta. Koperasi serba usaha "Karya Sembada" berdasarkan hasil Rapat Anggota Tahunan tanggal 29 Mei 2010 masa bakti 2015 -2018 
susunan pengurusnya adalah: Pembina : Direksi Perusda PPK Pedaringan Surakarta, Ketua :Umar Rois, Bendahara: Dharmastuti. Seksi Usaha yang ada: Simpan Pinjam: Supardi, Waserda : Sri Mardiyati dan akuntansi : Helmy Yusuf,SE,MM. Perlu diketahui bahwa Selama ini sistem pembiayaan yang diterapkan masih menerapkan sisten konvensional. Dalam rangka pencapaian tujuan koperasi serba usaha, Koperasi "Karya Sembada" selalu melaksanakan berbagai kegiatan antara lain :

1. Mengikuti Pelatihan Penyusunan Laporan Keuangan yang diadakan oleh Dinas Koperasi dan UMKM Kota Surakarta.

2. Pemeriksaan oleh Badan Pengawas Laporan, demi memeuhi amanat Anggaran Dasar Koperasi.

3. Mengikuti Penjelasan Pelaksanaan Diklat Sertifikasi Kompetensi Manajer.

4. Mengikuti Talk Show “ Koperasi Indonesia Menuju Ekonomi Global.

5. Mengikuti Pendidikan Perkoperasian yang diadakan oleh Dekopinda

6. Mengikuti pembinaan dari dinas Koperasi dan UMKM Kota Surakarta.

Koperasi "Karya sembada" sebagai koperasi serba usaha sebagaimana Koperasi pada umumnya mempunyai tujuan untuk memajukan kesejahteraan anggota khususnya dan masyarakat pada umumnya serta ikut membangun tatanan perekonomian nasional, dalam rangka mewujudkan masyarakat yang maju, adil dan makmur berlandaskan Pancasila dan Undang-Undang Dasar 1945. Fungsi Koperasi adalah sebagai berikut :

1. Membangun dan mengembangkan koperasi dan kemapuan ekonomi anggota pada khususnya dan masyarakat pada umumnya serta untuk meningkatkan kesejahteraan ekonomi sosial.

2. Koperasi berperan secara aktif dalam upaya mempertinggi kualitas kehidupan manusia dan masyarakat.

3. Memperkokoh perekonomian rakyat sebagai dasar kekuatan danketahanan perekonomian Nasional dengan koperasi sebagai sokogurunya.

4. Koperasi berusaha untuk mewujudkan dan mengembangkan perekonomian Nasional yang merupakan usaha bersama berdasar atas asa kekeluargaan.

Koperasi Serba Usaha, koperasi serba usaha merupakan badan usaha yang didirikan dan dikelola oleh sekelompok masyarakat untuk memenuhi aspirasi dan kebutuhan bersama anggota pada khususnya dan masyarakat pada umumnya dibidang ekonomi. Secara umum koperasi dipahami sebagai perkumpulan orang yang secara sukarela mempersatukan diri untuk berjuang meningkatkan kesejahteraan ekonomi mereka melalui pembentukan sebuah badan usaha yang dikelola secara demokratis (Rudianto; 2010: 3). Menurut PSAK No.27 Revisi 1998, Reformat 2007) tahun 2009 menyatakan koperasi adalah badan usaha yang mengorganisir pemanfaatan dan pendayagunaan sumber daya ekonomi para anggotanya atas dasar prinsip-prinsip koperasi dan kaidah usaha ekonomi untuk meningkatkan taraf hidup anggota pada khususnya dan masyarakat daerah kerja pada umumnya. Dengan demikian,koperasi merupakan gerakan ekonomi rakyat dan sokoguru perekonomian nasional. Koperasi Serba Usaha memiliki beberapa fungsi yaitu :

a. Perkreditan

b. Penyedian dan penyaluran sarana produksi dan keperluan sehari-hari.

c. Pengelolaan serta pemasaran hasil.

Tujuan Koperasi Serba Usaha :

1. Mensejahterakan anggota koperasi serba usaha pada khususnya dan masyarakat pada umumnya.

2. Dapat membangun tatanan perekonomian untuk mewujudkan masyarakat maju, adil, dan makmur.

3. Memberikan pelayanan pinjaman dengan bunga murah, tepat dan cepat serta mendidik anggota untuk dapat menggunakan uang dengan bijaksanan dan produktif,

4. Kebutuhan sehari- hari dan perkantoran anggota koperasi. 
Dengan memperhatikan tujuan dan fungsi koperasi serba usaha tersebut, maka koperasi " Karya Sembada" berharap adanya peningkatan kedisiplinan dan peran aktif yang tinggi dari anggota pada umumnya dan khususnya bagi pengurus dalam memahami kewajiban dan tanggungjawab kepada koperasi.. Dalam pelaksanaan kegiatan koperasi masih terdapat adanya kekurangan- kekurangan ,untuk itu masih mengharapkan adanya saran masukan yang bertujuan untuk membangun dan mengembangkan koperasi sehingga tujuan dari koperasi " Karya Sembada" akan benar-benar dapat terwujud.

Pelaksanaan kegiatan tim Pengabdian Kepada Masyarakat Sekolah Tinggi Ilmu Ekonomi Adi Unggul Bhirawa (STIE“AUB”) Surakarta ini akan berusaha membantu memberikan pendampingan tentang pemahaman manajemen syariah bagi pengurus dan anggota. Hal ini atas permintaan pengurus agar dapat memberikan masukan -masukan tentang gambaran tentang bagaimana pelaksanaan pengelolaan sistem pembiayaan syariah sehingga dengan pemahaman tersebut para pengurusdan anggota dapat memahami sebagai wawasan baru tentang kaidah dan prinsip manajemen syariah, apabila ingin mengembangkan sistem pembiayaannya yang selama ini masih sistem konvensioanal menuju ke pembiayaan sistem syariah.

\section{METODE}

Metode yang digunakan dalam kegiatan ini adalah sebagai berikut :

a. Penyampaian materi ceramah tentang prinsip - prinsip dasar Manajemen Syariah.

b. Penyampaian materi ceramah Prinsip Titipan atau Simpanan ( Al - Wadiah) yang meliputi : Prinsip Al- Mudharabah dan Prinsip Al- Musyarakah

c. Memberikan pendampingan gambaran contoh transaksi dan masalah dari sistem pembiayaan syariah sebagai tindak lanjut akan melakukan pendampingan prosedur menuju sistem pembiayaan dengan sistem syariah.

\section{HASIL, PEMBAHASAN DAN DAMPAK}

Hasil luaran kegiatan pengabdian kepada masyarakat ini adalah pengurus dan anggota koperasi khususnya dibidang usaha simpan pinjam mampu mengetahui dan memahami serta menerapkan kegiatan usaha pembiayaan dengan sistem manajemen syariah sebagai langkah menuju pengembangan usaha pembiayaan yang selama ini masih menggunakan sistem konvensional. Luaran wajib pengabdian masyarakat ini berupa jurnal ilmiah yang akan dipublikasi

\section{Prinsip Manajemen Syariah}

\section{-Prinsip Dasar Sistem ekonomi Syariah}

Prinsip - prinsip ini memberikan landasan dan panduan dalam menjalankan aktivitas perekonomian secara syariah.

Prinsip-prinsip tersebut antara lain berkaitan dengan kebebasan individu, hak terhadap harta, jaminan sosial, larangan menumpuk harta dan pentingnya distribusi kekayaan serta kesejahteraan individu dan masyarakat.

\section{Prinsip-prinsip tersebut akan kami uraikan sebagai berikut :}

\section{Kebebasan individu}

Kebebasan manusia dalam syariah didasarkan atas nilai- nilai tauhid, yaitu Suatu nilai yang membebaskan dari dari segala sesuatu, kecuali Allah, Kebebasan individu yang dimaksud bahwa manusia memiliki kesempatan yang luas untuk mengembangkan kreativitas, melakukan inovasi dalam kehidupan dunia.

\section{Hak terhadap harta}

Syariah mengatur kepemilikan harta didasarkan atas kemaslahatan bersama, sehingga keberadaan harta akan menimbulkan sikap saling menghargai dan menghormati. 


\section{Jaminan Sosial}

Dalam ekonomi syariah, Negara mempunyai tanggungjawab untuk mengalokasikan sumber daya alam guna meningkatkan kesejahteraan rakyat secara umum. Maka syariah memperhatikan pula masalah pengelolaan harta melalui pengaturan zakat, infaq, sedekah, dan sebagai sarana untuk mendapatkan kehidupan yang lebih sejahtera.

4. Larangan menumpuk Kekayaan dan Pentingnya Mendistribusikan harta.

Sistem ekonomi syariah membatasi, bahkan melarang setiap individu dengan alasan apapun menumpuk kekayaan dan tidak mendistribusikannya kepada orang lain. Sehingga seorang muslim sejati mempunyai keharusan untuk mencegah dirinya supaya tidak berlebihan dalam segala hal atau melampaui batas, karena sifat menumpuk kekayaan merupakan sifat yang rakus dan merugikan orang lain.

\section{Individu Kesejahteraan dan Masyarakat}

Pengakuan akan hak individu dan masyarakat sangat diperhatikan dalam syariah. Masyarakat akan menjadi faktor yang dominan dalam pembentukan sikap individu sehingga karakter individu banyak dipengaruhi oleh karakter masyarakat.

Selain prinsip- prinsip yang dikemukakan tersebut diatas, menurut Hidayat

(2003), prinsip- prinsip yang mendasari ekonomi syariah antara lain adalah :

1. Keadilan, yaitu kegiatan ekonomi yang dijalankan harus secara transparan dan jujur serta tidak ada eksploitasi terhadap lawan transaksi atas dasar kontrak yang adil.

2. Menghindari kegiatan yang merusak, yaitu larangan untuk melakukan transaksi atas barang- barang yang dapat merugikan dan membahayakan manusia dimana termasuk proses pembuatan produk tersebut.

3.Kemlasahatan, berarti tidak diperkenankannya spekulasi dan adanya pemerataan dalam hal kepemilikan akses yang sebesar besarnya bagi masyarakat untuk memperoleh sumber daya.

Prinsip- Prinsip Dalam Manajemen Perbankan Syariah

Dalam perbankan syariah menerapkan prinsip- prinsip yang konsisten berdasarkan tuntunan Al-Quran dan Hadis. Prinsip prinsip bank syariah menyangkut beberapa permasalahan pokok antara lain :

1. Prinsip Titipan atau Simpanan ( Al-Wadiah)

Al Wadiah dapat diartikan sebagai titipan murni dari salah satu pihak ke pihak lain, baik individu maupun bagan hukum, yang harus dijaga dan dikembalikan kapan saja si penitip menghendaki. (Syafi'l Antonio,2001). Secara umum terdapat dua jenis Al-Wadiah, yaitu Wadiah yad al-amanah dan Wadiah yad adh- dhamanah.

a. Wadiah Yad Al- Amanah (Trustee Depository)

merupakan akad penitipan barang atau uang dimana pihak penerima titipan tidak diperkenankan menggunakan barang atau uang yang dititipkan dan tidak bertanggungjawab atas kerusakan atau kehilangan barang titipan yang bukan diakibatkan perbuatan atau kelalaian penerima titipan. Adapun aplikasinya dalam perbankan syariah berupa produk safe deposit box.

b. Wadiah Yad adh-Dhamanah (Guarantee Depository)

Merupakan akad penitipan barang atau uang dimana pihak penerima titipan dengan atau tanpa ijin pemilik barang/uang dapat memanfaatkan barang/uang titipan dan harus nertanggungjawab terhadap kehilangan atau kerusakan hakbarang/uang titipan. Semua manfaat dan keuntungan yang diperoleh dalam penggunan barang/uang titipan menjadi hak penerima titipan. Prinsip ini diaplikasikan dalam giro dan tabungan.

2. Prinsip Titipan atau simpanan ( Al Wadiah)

\section{a. Al- Mudharabah}

Mudharabah adalah suatu pengkongsian antara dua belah pihak dimana ) pihak pertama (shahib al-mal) menyediakan dana, dan pihak kedua ( 
mudharib) bertanggung jawab atas pengelolaan usaha.Keuntungan dibagi sesuai rasio laba yang telah disepakati bersama secara advance, jika rugi shahib al-maal akan kehilangan sebagian imbalan dari kerja keras dan ketrampilan manajerial selama proyek berlangsung. Al- Mudharabah juga dapat diartikan sebagai akad kerjasama dua belah pihak dimana pihak pertama menyediakan seluruh (100 \%) modal, sedangkan pihak lainnya menjadi pengelola (mudharib).Keuntungan usaha secara mudharabah dibagi menurut kesepakatan yang dituangkan dalam kontrak, sedangkan apabila rugi ditanggung oleh pemilik modal selama kerugian itu bukan akibat kelalaian si pengelola. Seandainya kerugian diakibatkan atau kelalaian kelalaian si pengelola, si pengelola harus bertanggungjawab atas kerugian tersebut. Akad mudharabaah secara umum terbagi dua jenis : Mudharabah Muthlaqah, yaitu bentuk kerjasama antara shahibul maal dan mudharib yang cakupannya sangat luas dan tidak dibatasi oleh spesifikasi jenis usaha,waktu, dan daerah bisnis. Mudarabah Muqayyadah, yaitu bentuk kerjasama antara shahibul mal dan mudharib dimana mudharib memberikan batasan kepada shahibul maal akan mengenai tempat, cara dan obyek investasi.

\section{b. Al- Musyarakah}

Musyarakah adalah pengkongsian antara dua belah pihak atau lebih dalam suatu proyek dimana masing-masing berhak atas

segala keuntungan dan bertanggungjawab akan segala kerugian yang terjadi sesuai dengan penyertaannya masing-masing. AlMusyarakah juga dapat diartikan sebagai akad kerjasama antara dua pihak atau lebih untuk suatu usaha tertentu dimana masing- masing pihak memberikan kontribusi dana dengan kesepakatan bahwa keuntungan dan resiko akan ditanggung bersama sesuai dengan kesepakatan.

Terdapat dua jenis al- Musyarakah, yaitu : Musyarakah kepemilikan, tercipta karena satu asset oleh dua orang atau lebih, dan Musyarakah akad, tercipta dengan cara kesepakatan dimana dua orang atau lebih stuju bahwa tiap orang dari mereka memberikan modal musyarakah.

Dampak dari kegiatan Pendampingan dalam pemahaman tentang usaha pembiayaan dengan prinsip syariah ini adalah koperasi Serba Usaha "Karya Sembada "Pusat Pergudangan Kota (PPK) Pedaringan Surakarta ,dapat meningkatkan pendapatan Sisa Hasil Usaha bagi anggota.

\section{PENUTUP}

\section{Simpulan}

Kegiatan pengabdian kepada masyarakat ini berupa pendampingan tentang pemahaman sistem pembiayaan syariah di Koperasi Serba Usaha "Karya Sembada” PERUSDA Pusat Pergudangan Kota (PPK) Pedaringan Surakarta memberikan kesimpulan sebagai berikut :

1. Para peserta sangat antusias mengikuti kegiatan pendampingan ini dikarenakan keinginan mereka dalam upaya untuk lebih memahami tentang bagaimana mengembangkan kegiatan usaha simpan pinjam yang masih sistem konvensional menuju sistem syariah yang baik.

2. Para peserta antusias menanggapi kegiatan pengabdian tim STIE'AUB Surakarta karena dengan memperoleh gambaran materi dan contoh gambaran pembiayaan syariah yang disampaikan akan berusaha memahami dan sebagai tindak lanjut berharap dapat mengembankan koperasi dengan sistem syariah 


\section{Saran}

Beberapa hal yang perlu digarisbawahi berdasarkan kesimpulan di atas adalah berupa saran untuk pengembangan pendampingan selanjutnya, tim pengabdian kepada masyarakat SIE"AUB" Surakarta dapat memberikan pendampingan lebih lanjut tentang mekanisme atau prosedur tentang manajemen koperasi yang berbasis syariah sebagai upaya pengembangan kegiatan usaha pembiayaan dengan menerapkan sistem syariah di koperasi "Karya Sembada” PERUSDA Pusat Pergudangan Kota (PPK ) Pedaringan Surakarta

\section{UCAPAN TERIMA KASIH}

Kegiatan Pengabdian Kepada Masyarakat ini terlaksana berkat bantuan dan kerjasama yang baik dengan berbagai pihak, untuk itu pada kesempatan ini kami ingin menyampaikan ucapan terima kasih kepada :

1. Ketua STIE “AUB” Surakarta yang mempercayakan dan memberikan dana kepada Tim Pengabdian Kepada Masyarakat.

2. Umar Rois,SE,MM selaku ketua Koperasi Serba Usaha "Karya Sembada" yang telah memberikan waktu untuk pelaksanaan kegiatan Tim Pengabdian kepada Masyarakat STIE "AUB" Surakarta.

3. Pengurus dan anggota Koperasi Serba Usaha "KARYA SEMBADA" PERUSDA Pusat Pergudangan Kota (PPK) Pedaringan Surakarta yang telah mengikuti kegiatan pendampingan tentang pemahaman pengembangan usaha pembiayaan sistemsyariah.

4. Semua pihak yang telah membantu kelancaran pelaksanaan kegiatan ini.

\section{REFERENSI}

An Nabahan, M.Faruq, 2000, Sistem Ekonomi Syariah, Terjemahan, Yogyakarta :UII Pres Baswir, Revrisond Baswir, 2000, Koperasi Indonesia,Edisi Pertama, Yogyakarta,FEUGM

Buchari Alma, Donni Juni Priansa, 2009, Manajemen Bisnis Syariah, Alfabeta, Bandung. Dewan Syariah Nasional, 2003, Himpunan Fatwa Dewan Syariah Nasional, Edisi 2, Bank Indonesia- Dewan Syariah Nasional.

Pachta W, Anjar, 2007, Hukum Koperasi Indonesia Pemahaman, Regulasi, Pendidikan, dan Modal Usaha, Jakarta, Kencana Predana Media Group

Rudianto, 2010, Manajemen Akuntansi Koperasi,Erlangga, Jakarta

Sitio, Arifin dan Halomom Tamba, 2001, Koperasi Teori dan Praktik, Jakarta, Erlangga 